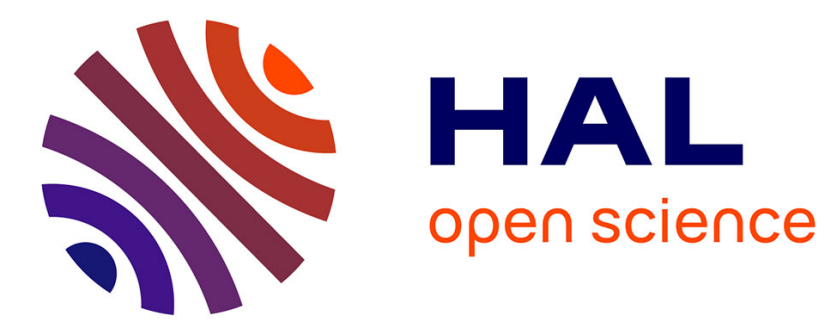

\title{
PULSED LASER PHOTOACOUSTIC SPECTROSCOPY OF GASES
}

P. Vujkovic Cvijin, M. Terzic, D. Markusev, A. Petrovic, J. Jovanovic-Kurepa, G. Atkinson

\section{- To cite this version:}

P. Vujkovic Cvijin, M. Terzic, D. Markusev, A. Petrovic, J. Jovanovic-Kurepa, et al.. PULSED LASER PHOTOACOUSTIC SPECTROSCOPY OF GASES. Journal de Physique IV Proceedings, 1991, 01 (C7), pp.C7-477-C7-480. 10.1051/jp4:19917126 . jpa-00250776

\section{HAL Id: jpa-00250776 https://hal.science/jpa-00250776}

Submitted on 1 Jan 1991

HAL is a multi-disciplinary open access archive for the deposit and dissemination of scientific research documents, whether they are published or not. The documents may come from teaching and research institutions in France or abroad, or from public or private research centers.
L'archive ouverte pluridisciplinaire HAL, est destinée au dépôt et à la diffusion de documents scientifiques de niveau recherche, publiés ou non, émanant des établissements d'enseignement et de recherche français ou étrangers, des laboratoires publics ou privés. 


\title{
PULSED LASER PHOTOACOUSTIC SPECTROSCOPY OF GASES
}

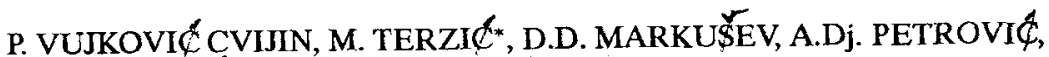 \\ J. JOVANOVIĆ-KUREPA and G.H. ATKINSON**
}

Institute of Physics, P.O. Box 57, YU-11001 Belgrade, Yugoslavia

${ }^{*}$ University of Novi Sad, Institute of Physics, P.O. Box 224, YU-21001 Novi Sad, Yugoslavia

${ }^{* *}$ Department of Chemistry, University of Arizona, Tucson, Arizona 85721, USA

\begin{abstract}
Pulsed laser photoacoustic spectrometer based on $\mathrm{CO}_{2}$ laser excitation is reported. Advantage has been taken of the temporal resolution of the gas absorption signal relative to that of the background. Detection sensitivity of 1.5 ppbv ethyene $\left(4.9 \times 10^{-8} \mathrm{~cm}^{-1}\right)$ is achieved.
\end{abstract}

Background Information

Pulsed laser excitation is an alternative experimental approach to photoacustic spectroscopy and detection, relative to modulated cw lasers. The technique provides temporal resolution of the photoacoustic signal (vs. phase resolution in modulated cw technique), which makes it feasible to separate the molecular gas absorption signal from the background window and cell wall absorption. Since the sensitivity of the photoacoustic detection is mainly limited by the magnitude of the background signal, rejection of a large portion of it by temporal resolution leads to a high signal/noise ratio $|1-2|$.

The specific experimental technique and the corresponding detection sensitivity was demonstrated previously by investigating the detection of $\mathrm{SO}_{2}$ in the UV 1|. The simpler of the two systems investigated was based on the fixed frequency Xec1 excimer laser (laser wavelength: $308 \mathrm{~mm}$ ) and was found to have the sensitivity limit of $2 \mathrm{ppbv}$ of $\mathrm{SO}_{2}$. Better matching of the excitation wavelength with a $\mathrm{SO}_{2}$ absorption line was achieved with our second system based on a continuously tunable frequency doubled pulsed dye laser operating at $300.05 \mathrm{~nm}$. This system achieved the detection 1imit of $0.2 \mathrm{ppbv}$ of $\mathrm{SO}_{2}$, corresponding to the absorption coefficient of $2.9 \mathrm{x}$ $\mathrm{x} 10^{-9} \mathrm{~cm}^{-1}$. Linear dependence of the photoacoustic signal on $\mathrm{SO}_{2}$ concentration was established for at least 5 orders of magnitude. Photoacoustic detection of gaseous formic and acetic acids in the UV was subsequently demonstrated with a similar experimental setup $|2|$.

Since the middle IR region contains a wealth of absorption lines of many gases of interest, especially for pollution monitoring, a study was initiated to explore the potentials of pulsed IR photoacoustic spectroscopy. This paper reports the results of investigation of detection sensitivity and the influence of some interfering species.

\section{Experimental Apparatus}

The experimental apparatus (Fig.1) uses a line tunable TEA pulsed $\mathrm{CO}_{2} \mathrm{I}_{\text {aser }}$ (Tachisto 215G) adjusted to deliver $100 \mathrm{~m}$ per pulse in the TEM mode. Nominal laser pulse repetition frequency is $1 \mathrm{~Hz}$. Laser output energy is monitored by a pyroelectric joulemeter (Gen-Tec ED-200). Computer controlled laser wavelength tuning is also available $|3|$. The photoacoustic cell is of cylindrical shape $(25 \mathrm{~cm} 10 \mathrm{ng}, 2.7 \mathrm{~cm}$ inside diameter), closed with Brewster angle windots. The cell contains an extension 


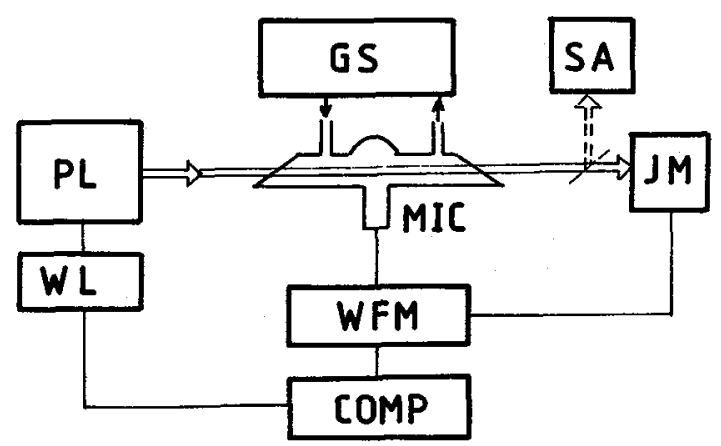

Fig.1. Experimental arrangement: PL-pulsed $\mathrm{CO}_{2}$ laser; WL-wavelength positioning sistem; GS-gas sampling system: SA-spectrum analyzer; MIC-microphone; JMjoulemeter; WHM-digital waveform recorder; COMP-computer.

opposite to the microphone to avoid the interference of the acoustic wave reflected from the cell wall $|1|$. A condenser microphone (Bruel and $\mathrm{Kj}$ aer 4166 with 2619 preamplifier) is used to monitor the acoustic signal.

Both the acoustic waveform and the laser excitation energy are digitized by a waveform recorder (Keithley/MetraByte PCIP-Scope plug-in board). Data acquition and processing is performed by a personal computer (IBM PC compatible).

Acoustic waveforms can be either on-line analyzed or stored for subsequent analysis. The analysis includes the calculation of the photoacoustic signal amplitude and its normalization to the laser excitation energy.

The gas sampling system is based on two-stage dilution of accurately measured, higher concentration gas mixture. Certified gas mixture (Matheson Gas Products), independent ly calibrated by gas chromatography/mass spectrometry is used as the starting gas mixture which is subsequently diluted to produce lower concentrations varying over more than three orders of magnitude.

Experimental Results and Discussion

The sensitivity of the pulsed laser photoacoustic apparatus is investigated by using ethylene $\left(\mathrm{C}_{2} \mathrm{H}_{4}\right)$ as the target gas. Ethylene gas mixtures are convenient to work with and its absorption coefficients at $\mathrm{CO}_{2}$ laser wavelengths are well known $|4|$. Calibrated mixture of 13 ppmv ethylene in synthetic air is diluted to the required concentration levels by the gas sampling system. Waveform of the pulsed photoacoustic signal for ethylene is presented on Fig.2 (solid line). Subsequent peaks on the acoustic waveform (not presented on Fig.2) also exist, resulting from the cell window (and to a lesser extent, wa11) absorption. Amp1itude of the gas molecular signal is measured and normalized to the laser excitation energy. Resulting quantity is proportional to the gas absorbance. For detection sensitivity studies with ethylene, $10 \mathrm{P}(14) \mathrm{CO}_{2}$ laser line with the highest ethylene absorption coefficient $|4|$ is used. Excitation energy of $100 \mathrm{~mJ}$ per pulse is found to be appropriate, still avoiding optical saturation. The dependence of the photoacoustic amplitude on ethylene concentration is presented on Fig.3. 100 laser pulses are averaged for each concentration on Fig.3. The detection limit of the apparatus, defined as the absorbing gas concentration which corresponds to the signal to noise ratio equal to unity, is found by extrapolation from the data on Fig.3. In this way, the detection limit is found to correspond to $1.5 \mathrm{ppbv}$ of ethylene, which results in the minimum detectable absorption coefficient of $4.9 \times 10^{-8} \mathrm{~cm}^{-1}$. This detection sensitivity compares favorably with the sensitivity of modulated $\mathrm{cw}$ technique $|5|$. It should be noticed that a larger number of averaged pulses than the one currently used (100) would increase the detection sensitivity correspondingly.

Atmospheric trace gas detection, however, is in practice typically limited by interferences from other atmospheric constituents than the one being measured. 


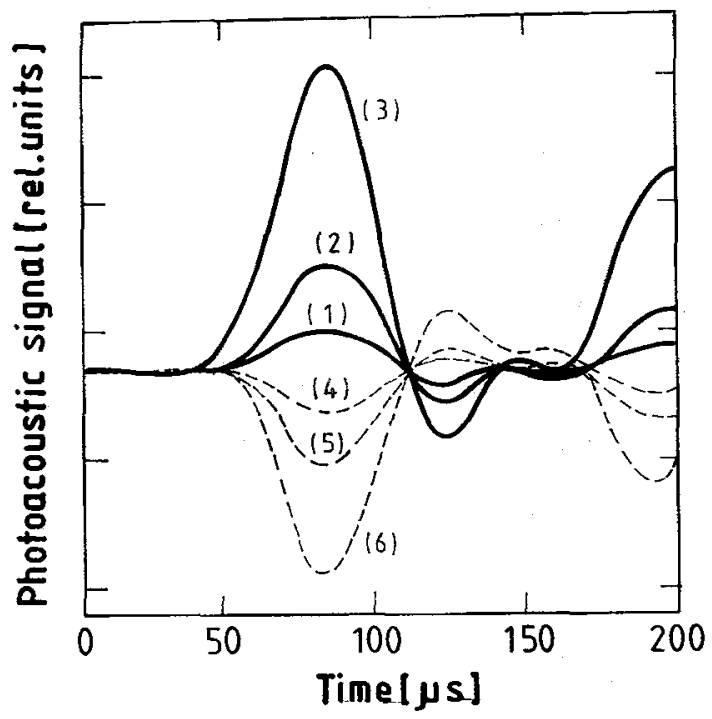

Fig.2. Photoacoustic signal waveforms - ethylene: (1) $-619 \mathrm{ppbv}$, (2) $-227 \mathrm{ppbv}$, (3) $-84 \mathrm{ppbv}$; carbon dioxide: (4)-292ppmv, (5)-440ppmv, (6)-880 ppmv.

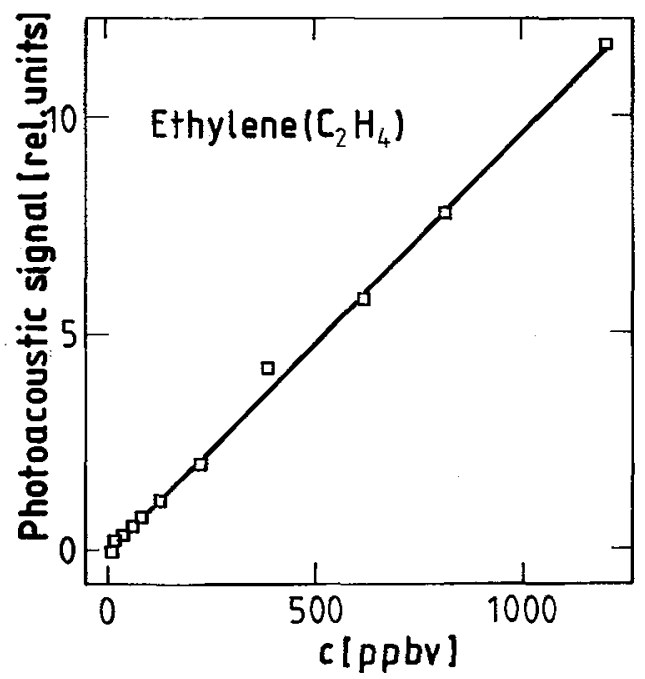

Fig.3. Dependence of the photoacoustic signal on ethylene concentration. 
The role of carbon dioxide $\left(\mathrm{CO}_{2}\right)$ in this process is of special interest, because of the effect of kinetic cooling, resulting in an inverse photoacoustic signal $|6|$. In order to investigate this effect with pulsed $\mathrm{CO}_{2}$ laser excitation, the photoacoustic signal from $\mathrm{CO}_{2}$ in synthetic air $\left(\mathrm{N}_{2} / \mathrm{O}_{2}\right)$ is measured at $10 \mathrm{P}(14)$ line (Fig.2, dashed line). Experiments performed with real atmospheric samples containing both $\mathrm{CO}_{2}$ and water vapor, did not reveal inverse signals, since the conditions for kinetic cooling are not fulfilled $|6|$. Experiments to further quantify the $\mathrm{CO}_{2}$ and water vapor interference with short pulse excitation are underway.

Conclusions

From the application point of view, pulsed photoacoustic apparatus is potentially advantageous over the modulated $\mathrm{cw}$ one. To obtain the same sensitivity, modulated $\mathrm{cw}$ excitation is usually enhanced by either optical multipassing the excitation beam through the sample cell or by using acoustically resonant operation, or both. The acoustically nonresonant mode of operation of the pulsed technique is certainly advantageous for the field use. Compact pulsed $\mathrm{CO}_{2}$ lasers needed for this application are technologically completely feasible. The inherent simplicity of design, together with the measured level of performance, makes pulsed photoacoustic spectrometer a strong candidate for the development of a photoacoustic trace level monitor of gases for field use.

\section{Acknowledgment}

The research on IR pulsed photoacoustic spectroscopy was supported by NSF/Yugoslavia Joint Board for Scientific Cooperation under project JU796. Experimental work was carried out in the Institute of Physics, Belgrade, Yugoslavia.

\section{References}

1. P.Vujković Cvijin, D.A. Gilmore, M.A.Leugers and G.H.Atkinson, Ana1. Chem.59, $300(1987)$

2. P.Vujković Cvijin, D.A.Gilmore and G.H.Atkinson, App1. Spectrosc. 42, 770 (1988)

3. D.Ignjatijević, P.Vujković Cvijin, M.Srećković and I.Pippi, Opt. Las. Techno1. 17, 96. (1987)

4. J.Hinderling, M.W.Sigrist and F.K.Kneubuh1, Infrared Phys. 27, 63 (1987)

5. M.W.Sigrist, J.App1. Phys. 60, R83 (1986)

6. A.D.Wood, M.Camac and E.T.Gerry, App1. Opt. 10, 1877 (1971) 